\title{
The sciences of the earth in the epistolary archives of the Barnabite scientists
}

\author{
Filippo Lovison \\ Centro Studi Storici dei PP. Barnabiti, Roma, Italy
}

\begin{abstract}
This short paper intends to highlight the uniqueness of scientific commitment - not rarely of a high level - of some members of religious orders who, among other duties of their sacerdotal ministry, dedicated themselves particularly to in the study of sciences of the earth, realizing as such a fertile union between «pity and science», typical of the common spiritual and cultural formation of members of the Regular Clerics of Saint Paul, called Barnabites.
\end{abstract}

Key words Barnabites - letters - seismology - meteorology - 19th century

\section{Introduction}

The valuable study of Barnabites' scientific correspondence finds naturally its privileged $h u$ mus in the Archives - «place of memory» par excellence - always more fluctuating between the demands of preservation and those of the valorization of documentary patrimony which jealously preserves $\left({ }^{1}\right)$. This constant tension, though in alternate phases, allows to glimpse today with more clarity the possibility to quash new «frontiers» on the usual controversial camp of accessibility and of the use of archivistic material. In fact, the choice of abandonment of comfort behind the lines of a mere documentary conservation is no longer tenable as end in itself, to open up to the multiple possibility of its adequate valorization, possible, also thanks to ex-

Mailing address: Dr. Filippo Lovison, Centro Studi Storici dei PP. Barnabiti, Piazza Benedetto Cairoli 117, 00186 Roma; e-mail: filovis@tin.it ternal collaboration, on the basis of the utilization of vanguard experimental techniques and the new innovative mode. The preserved patrimony in situ is certainly of interest not only for the history of the Order of the Barnabites, who is the first depositary, but also for the entire International scientific community. Before being an honor, however, it is no minor responsibility.

In the current state of the topic, and from known Archives, like the Vatican Secret Archive, which in some way creates an inclination among specialists in this field, the advantages from the application of such development politics appear remarkable:

- First of all, for the Congregation to which these religious members belong, thanks to the congregation, famous scientists and that, thanks be to them, it can be made visible as a meaningful cultural depositary subject of their precious scientific inheritance;

- For the Archive concerned, particularly small ones, which can enter in to dialogue with the scientific Community benefiting from a specialistic collaboration, seeing to it as projected in a wide range and resonance in cultural projects, thanks also to those new possible management collaborations, such as digital scanning, of its documentary asset. 
- For the memory of those same religiousscientists. Escaping from the solitude in which - at times - they have been left by those who for various reasons were no longer able to make follow-ups to their studies and researches, can do resume the life of their thoughts and so bring their theories out from dust of their bookshelves. In this way their discoveries can be given values, in a more appropriate way, from the part of the same scientific Community who much appreciated and recognized the results, most of all through informal epistolary correspondence.

And, last but not the least, advantages for the same scientific Community, which in such a way notices the enrichment and the completion of the history of science, the history of scientific instruments and so on, filling the unavoidable gap and receiving new impulses for research.

This pioneering way for the Order of the Barnabites is just at the start. The other public, private and ecclesiastical archives all question on the problems raised through the use of the new means offered by modern technology, on the fixation of the limits of utilizing paper materials reproduced with digital scan, on the safeguard of property rights, on the protection of «archivistic» authorship of the documents $\left({ }^{2}\right)$.

The concern for this field of historical research is simplified by the proliferation of publications concerning epistolary correspondence regarding very different aspects of the life and word of the illustrious civil and ecclesiastical personalities, such as scientific correspondence of today by religious astronomers, meteorologists, volcanologists, etc. the scientific correspondence is hence destined to play a more meaningful role in the reconstruction of personal scientific journey and the paradigms of reference, furnishing a remarkable contribution in to research.

\section{Science in the convent}

In this particular light, we have to point out that the attention for science in general has accompanied the Barnabites throughout their centuries-old activities $\left({ }^{3}\right)$. Since the opening of the first public schools in 1608 - even «delayed» with respect to other religious families like the
Jesuits - they worked for science, particularly in the study of natural philosophy. Though suffering enough, they did not stop, not even before the apparent disagreement between «science and faith», caused by the topic of biblical inherence. So, many Barnabites in the 17th century applied the experimental method with diligence, reaching in the 17th century a distinct scientific orientation of Cartesian matrix, to the a point that the works of Copernicus, like those of Newton, can be well viewed in the Library of the mother house of Saint Barnabas in Milan $\left({ }^{4}\right)$.

In the beginning of the 17th century the scientific, physics and mathematical disciplines, entered fully into the scholastic teaching of the Order, giving a wide space in the colleges to experimental method. Even if the illustrious scientists who alternated themselves among those teaching posts were not like or inexplicable meteors that appear unexpectedly in the firmament of the small but lively life of the Order, there was a precise background, which well explains their extraordinary commitment and scientific success, in the great effort and, at times, in bitter misunderstanding.

One of the characteristics of the Barnabites' secular teaching tradition was that it has never limited itself only to the literary field, leaving ample space to the scientific, most of all when the teaching of the sciences was at its start and not expected in the schools $\left({ }^{5}\right)$.

So in the beginning of the 19th century Carlo Porta, Meneghin poet, in his famous caudate sonnet in which enumerated the best Milanese brains, in the field of physics nominates only four barnabites: «Risega, Racagn, De Regis, Pin»; namely the fathers Paolo Frisi (17281784) $\left({ }^{6}\right)$, mathematician and astronomer, Giuseppe Racagni (1742-1822), Francesco De Regi (1720-1794), mathematician and plumber and, Ermenigildo Pini (1793-1835), scientist and naturalist.

In the 19th century we can see the Congregation structuring itself as an extraordinary scientific laboratory.

Every school sees scientific teaching posts of national and international fame; every college has its astronomical observatory, often financed by the Father General; every community had its seismic and meteorological observa- 


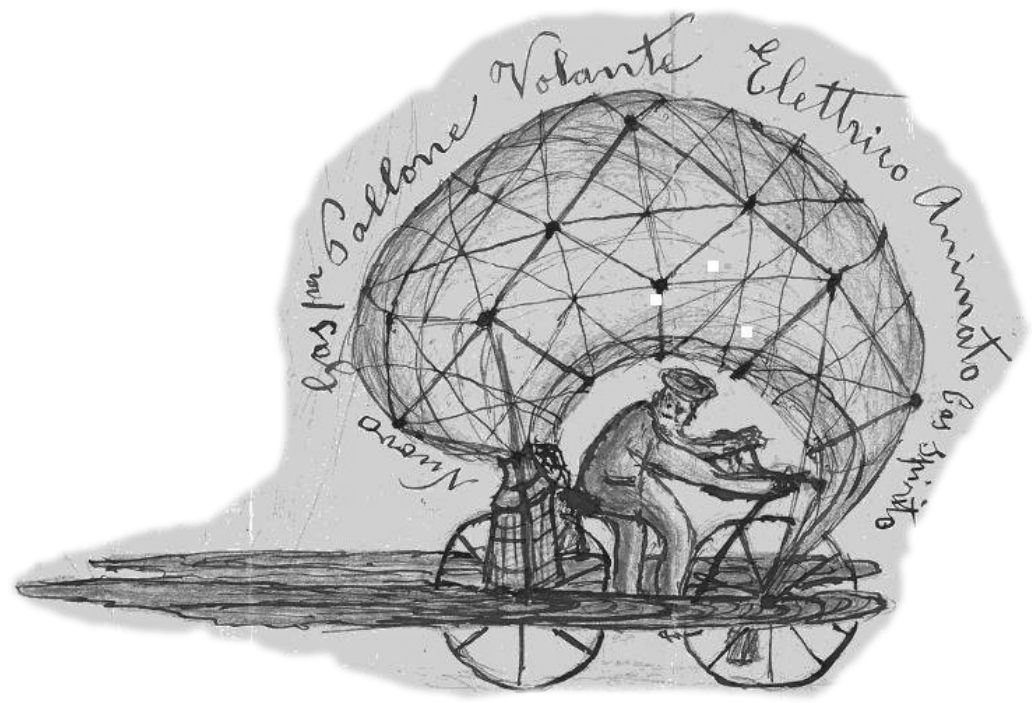

Fig. 1. Detail of a letter to T. Bertelli with the project for the gas-driven velocipide (Historical Barnabite Archives, Rome)

tory, even if at times relegated to a bell tower cell, but always with great attention to the scientific method.

Every scientific branch boasted its experts: from astronomy to seismology, from meteorology to botany, from mathematics to numismatics, from archeology to egyptology, without mentioning the literary side.

Among others we recall: Ambrogio Mazenta (1565-1635), architect and plumber; Redento Baranzano (1590-1622) scientist and astronomer ( ${ }^{7}$ ); Angelo Cortenovis (Bergamo 1727-1801); Francesco Stella (1745-1800) in Udine, wo was the first in Italy to elevate aerostatic balls in the sky on that memorable February 24 1783, while the Montgolfier brothers held such experiment at Annonay on the 5th of June in that same year; Giovanni Cavalieri (1807-1874), optician, physician, astronomer, professor of physics and sciences at the college of Monza $\left({ }^{8}\right)$, Pietro Monte (Tonengo di Mazzè, August 21, 1823), professor in Mathematics and physics, as well as founder of the Astronomical Observatory of Livorno $\left({ }^{9}\right)$; Bolognese by birth, but Florentine by deeds, Timoteo Bertelli $\left({ }^{10}\right)$ (1826-1905), seismologist, who opposed to Denza his system of the air causes of the variation of the pendulum; the Neapolitan Francesco Denza $\left({ }^{11}\right)$ (1834-1894), founder of the Italian Meteorological Company and director of the Vatican Observatory, the Observatory of Moncalieri and representative of the Society of the Tridentini Mountaineers and the Section of Domodossola of CAI; the Pisan Camillo Melzi d'Eril (1851-1929), seismologist and historian of science in Florence; the fathers Leonardo Matera $\left({ }^{12}\right)$ (1811ca.- 1871), teacher in mathematics, physics and philosophy, and Giuseppe Pellanda $\left({ }^{13}\right)(1865-1928)$ in Naples; Luigi Guanzati $\left({ }^{14}\right)$ (1757-1836), «naturalist» philosopher known for his studies on the infusers, in Lodi; Giuseppe Boffito (1869-1944, historian of science and technique, bibliographer of aeronautics and meteorology, learned and distinguished bibliophile $\left({ }^{15}\right)$.

All this spilled out naturally in the teaching of the students, who in their scholastic essays amazed everyone, declaring themselves capable 
- and they truly were - to resolve «whatever equation and whatever problem» $\left({ }^{16}\right)$.

The level of instruction was so high, it was more than enough to look through those essays at the end of the school year that might pale the students of today, and even some professors, as shown by the presence of the countless scientific instruments still kept today in these old colleges, of fundamental importance for the study of Science $\left({ }^{17}\right)$.

Entire colleges dedicated themselves to the study of the science of the earth.

For example the schools of the Barnabites in Udine (1679-1810), with their academies of agriculture which should have given the peasants the necessary agrarian instruction, a conception of science, as that of a practical knowledge addressed to the satisfaction of the real needs of existence.

Among all in this field the Barnabite Angelo Cortenovis distinguished himself as a man of great intellectual stature, in charge of the Collegio udinese S. Lorenzo Giustiniani, in epistolary contact with major scholars of his time, who was nominated in 1788 Perpetual Secretary of the Academy of Udine, who welcomed the introduction in the college of subjects connected to the science of agriculture, presented to him by Antonio Zanon.

This was not only studied, but also happily applied in the territorial visits and in the appreciated agricultural academies $\left({ }^{18}\right)$.

\section{The epistolary archives}

First of all, it is necessary to take note that a history of the scientific culture among the Barnabites has not yet been written. There is not even an account of the monographs and updated scientific biographies of much more important exponents from the 17 th century up to this period, like for example the fathers Baranzino, Modroni and Mazenta. Based on the incomplete and insufficient work of cataloguing done from then and also based on the dispersion of the correspondence, is not possible to present an approximate frame of volume on the size of the epistolary archives of the Barnabite scientists present in Italy, concentrating instead on major details on the Historical Archives of the Barnabites of Rome (ASBR) ${ }^{19}$ ). Giving a brief overview of the archives of the Order to have an idea of their consistency it is enough to consider the heritage represented by around 9000 letters with around 1,400 senders only to Fr. Francesco Denza, who worked in the Reale Collegio «Carlo Alberto» of Moncalieri. The largest number of letters to Fr. Denza are preserved in the ASBR in Rome and part of those are at the Vatican Observatory. About Cavalleri we can say that he was in correspondence with numerous scientists of his time, for example with G.B. Amici (the correspondence is kept in the Estense of Modena), with A. Secchi (some letters addressed to him are conserved in the Archives of San Barnaba), with G. Schiapparelli, with Timoteo Bertelli, etc.

In the ASBR of Rome we can find interesting epistolary correspondence regarding the earth sciences, especially in relation to Melzi, Bertelli and Boffito. In particular:

- Folder Melzi-Alfani, 1: Contains interesting letters regarding, for example, the tromometric observations in the two earthquake shocks of November 29, 1986, indicating the values of the length of the pendulum and the length of trace (Guido Alfani, Collegio vescovile di Gavi (Livorno), December 2, 1896).

- Folder Me, 1, Family and general letters with scientific character.

- Bertelli Archive, Epistolary, 1861-79, Folder I.

- Bertelli Archive, Epistolary, 1870-1904, Folder II.

- Epistolary and Scientific material of various kinds not in catalogue, notes, schemes, designs, etc., existing in many other folders (fig. 1).

- Folder Me, 3, Scientific Correspondence to Fr. Melzi no. $21\left({ }^{20}\right)$.

- Boffito Archive. Composed of various folders which chronologically divide all his most abundant sent and received correspondence; around 4000 writings, with correspondents from every side of the earth, private bodies and institutes like Universities, Libraries, Meteorological and Astronomical Observatories, etc. Some senders are particularly famous: Giovanni Gentile, Benedetto Croce, Arturo Graf and, in particular, in as much as interested in this study the meteorologist G. Hellman, Francesco Porro $\left({ }^{21}\right)$. 


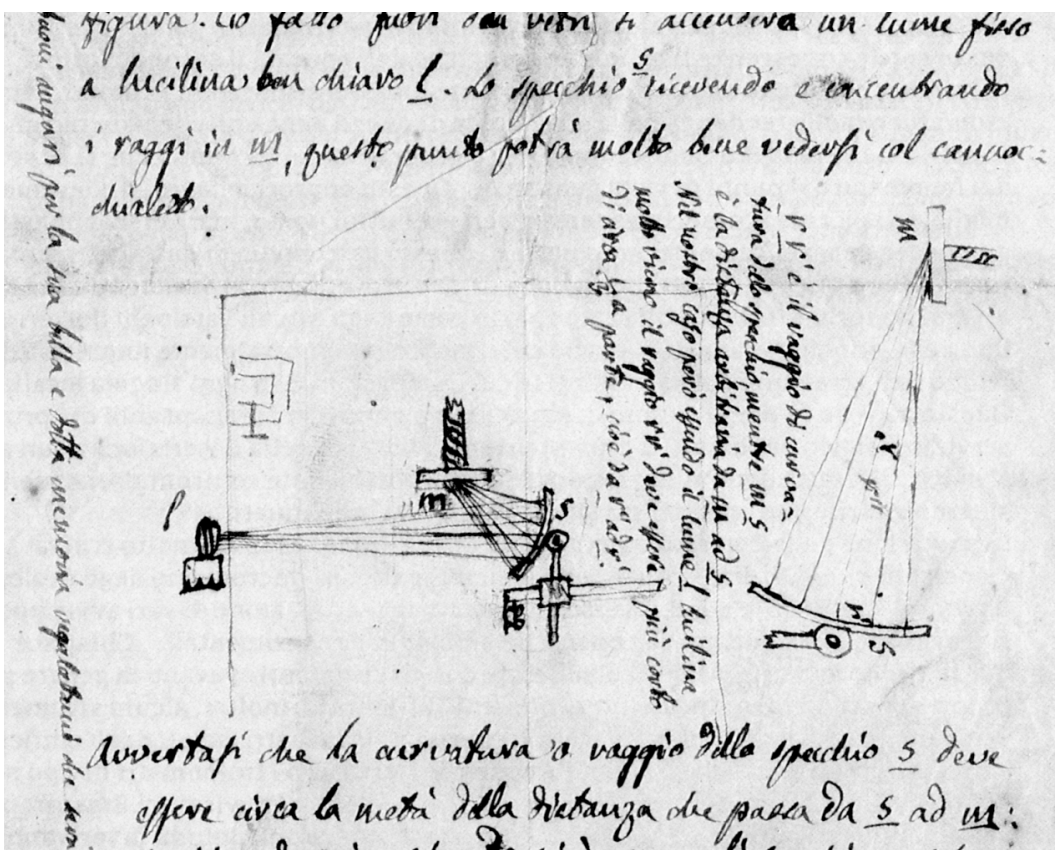

Fig. 2. Detail of a letter by G. Cavalleri to T. Bertelli, [Monza] 24th [March] 1874, in which the brother gives some suggestions on the illumination system of the tromometer measuring apparatus (Historical Archives of Barnabites, Rome).

Only a small part of this important heritage was used in the 1990 s by G. Ferrari $\left({ }^{22}\right)$ in the TROMOS project to reconstruct an important experimental path started in 1870 by Bertelli and that led to the invention of the normal tromometer, in collaboration with De Rossi, the first instrument for the observation of earthquakes installed in about fifty public and private Italian observatories.

In particular, by means of the letters received by Bertelli between 1861 and 1879 Ferrari (1991) reconstructs the different phases of the design of the instrument and its complex and controversial affirmation among Italian scholars affiliated to the network of correspondents of the Bullettino del Vulcanismo Italiano, the first geodynamics review in the world, founded, drafted and funded by De Rossi from 1874 to 1898 . Of the over 500 letters received by Bertelli between 1861 and 1905, the year of his death, 208 were used by Ferrari to illustrate the working hypotheses, the methodological and practical difficulties encountered by Bertelli and De Rossi, the discussions born among the scholars on the design and methodological work of Bertelli (fig. 2).

The most intense correspondence is that exchanged with De Rossi (77 letters), Filippo Cecchi (16), director of the Ximeniano Observatory of Florence and worthy designer of seismic instruments, Luigi Guidi (10) director of the Observatory of Pesaro, Cavalleri (6), Barnabite brother, whose great experience in testing instruments was of fundamental help for the work of Bertelli.

The correspondence with De Rossi was at times almost daily and affected all the phases. Some letters are complete with explanatory drawings (fig. 3) with the design suggestions of De Rossi on the tromometer initially invented by Bertelli and completed by De Rossi himself. 


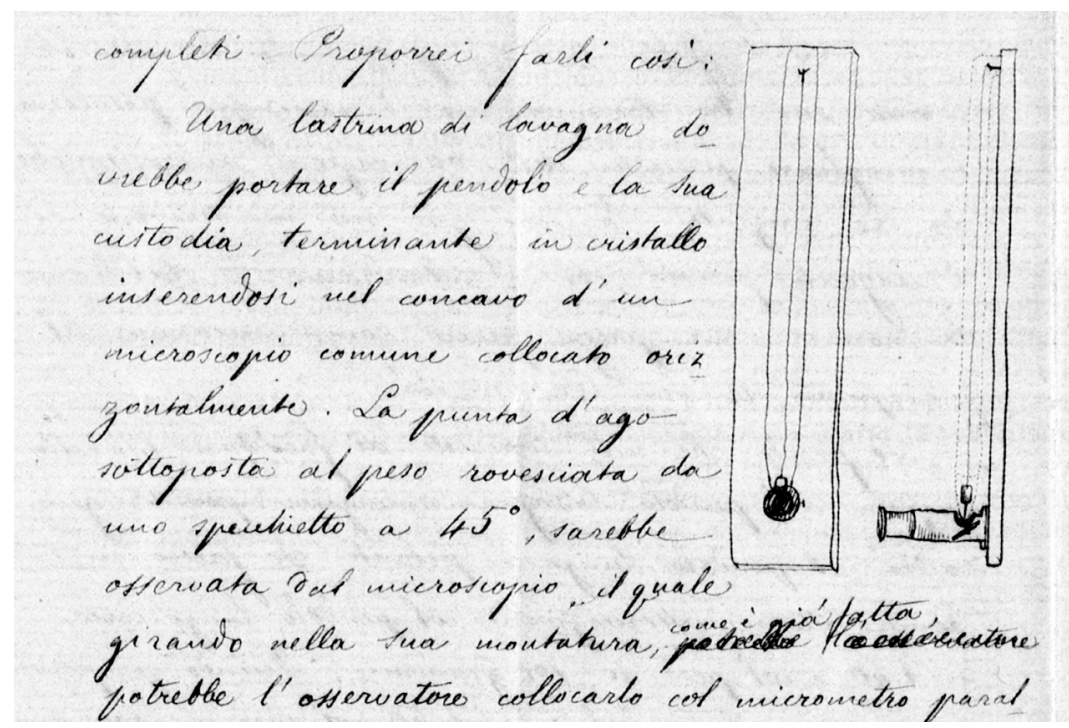

Fig. 3. Detail of a letter of M.S. De Rossi to Timoteo Bertelli, Rome, 10th March 1875, in which the scholar puts forward the definition and dissemination of a standard version of tromometer and makes a sketch of it (Historical Archives of Barnabites, Rome).

\section{Conclusions}

The aim of these few pages is therefore only to mark another small lap of that slow journey of those responsible for these archives towards the right equilibrium between preservation and valorization, for that debt of gratitude towards the cited illustrious Barnabite scientists, such as Giovanni Cavalleri, Timoteo Bertelli, Francesco Denza, Camillo Melzi d'Eril to whom the scientific world today looks at with deep gratitude.

The huge amount of letters of these important earth scientists is very important for future research both from the historical and scientific point of view.

History of meteorology from mid 19th century to 1920's and of seismology to 1930's will benefit greatly from the study of these letters. However, these objectives can only be achieved if the constant tension inside the archives between conservation and valorization is overcome.

Today it is possible to see more clearly the chance to quash new «frontiers» on the ever controversial field of the accessibility and use of archive material.

The choice of abandonment of comfort behind the lines of a mere documentary conservation as end in itself is no longer tenable, and the multiple possibility of its adequate valorization be made possible also thanks to external collaboration, on the basis of the utilization of vanguard experimental techniques and the new innovative mode.

The preserved patrimony in situ is certainly of interest not only for the history of the Order of the Barnabites, which is the first depositary, but also for the entire international scientific community. Before being an honor, however, itis no minor responsibility. 


\section{Notes}

$\left.{ }^{1}\right)$ The concept of «Place» is fundamental for the existence of an archive. Ulpiano, for example, defines it as «locus publicus in quo instrumenta deponuntur», not to be understood only in the mere sense and in passive material conservation, which instead of archivistic activity it is a less important aspect, but most of all in the acceptance of an active role of scientific research, which includes the arrangement, the inventory, and enhancement of different funds. Besides, the concept of «place» extends today even in «virtual» space. The Barnabites show their sensitivity with regard to this aspect since the choice of the name: Historical Studies Center given to their research organism, which recalls the type of a dynamic cultural subject, propulsor of the documentary exploitation. According to article 8 of its Statute, the Center poses its primary role as «to gather, to arrange, preserve and exploit the book trade and documentary asset of the Congregation [...]» and, beside the activity of the members which composes it, that is «to assist researchers [...], to participate in scientific and cultural manifestations which make them concern in whatever way of the Congregation [...], to maintain the relation with cultural institutions in the name of the Congregation».

$\left(^{2}\right)$ An experiment of this type, even though signed by understandable pauses of reflection, is actually of route through the concern of the Historical Studies Center, the Barnabite scientists engaged in the studies of sciences of the earth (Meteorology, Seismology, etc), like Francesco Denza, Timoteo Bertelli, Camillo Melzi D’Eril. Thanks to the SGA (Storia Geofisica Ambiente di Bologna - Geophysical Environment History of Bologna), it entered in the project Tromos - an important project of scientific and historical recovery and of the enhancement of the Italian seismological tradition, actuated under the patronage of the National Institute of Geophysics and Volcanology (INGV) - that intends to enhance the scientific correspondence on sciences of the earth and to promote the salvation and the enhancement of the scientific instrumentation. This collaboration, already developed in 1986 with the college «Alla Querce» in Florence, has brought up to the reproduction to microfilm and/or electronic as part of scientific materials conserved therein, and between 1990 and 1992 proceeded to the restoration, and in part to the exposure in national exhibits, of the instruments of Bertelli, as well as the publication of the different volumes with the results of the the said researches (FERRARI and BIANCHI, 1997; FERRARI, 1991; 1997). $\left({ }^{3}\right)$ Cfr. in particular, for the study of the Arcimboldi Schools inaugurated in Milan in November 3, 1608 (BIANCHI, 2002).

$\left({ }^{4}\right)$ The Barnabite method in fact left ample freedom to the teaching staff to follow «where it doesn't deal with definite things or from the established universal consensus, those sentence which might be better and well grounded to each one, far be it from every spirit of decision» (Erba, 1981).

$\left.{ }^{5}\right)$ Such «subtle feelings» were present in the DNA of the Order, which even the missionaries that departed, for example, for the mission in the kingdoms of Ava and Pegù (Burma, now Myanmar) in the 18th century, could not make without dedicating themselves, even in those far lands in south-east asia, to scientific research, particularly as regards the sciences of the land that they covered in Italy the teaching posts in theology, arts, philosophy, etc., in different colleges of their own Order and, even at prestigious Universities. For this reason they were able to give a fundamental scientific contribution to the cultural development of the country. Their expertise in phenomena of astrology, mathematics, physics, cartography (a subject that they teach at Bramini), and their single studies, must not be forgotten, like that, for example, of P. D'AMATO, with his Short description of the mines of Precious Stones, in the District of Kiat-pyen in the Kingdom of Ava. Moreover Msgr. Gaetano Mantegazza made the first scientific treatment of history, geography and ethnography of the country, with his Realation of the kingdoms of Ava and Pegù, dated 1784. this was equipped by the first two much important geographic maps of Burma).

$\left({ }^{6}\right)$ BARBARISI, 1987.

${ }^{(7)}$ Author of the Uranoscopia seu de coelo, Geneva 1617 and the Nova de Motu Terrae Copernicano justa Summi Pontificis Mentem Disputatio, Coloniae Albrogum, apud Petrum et Jacobum Chouet, 1617. Of particular importance is his epistolary, where the letter of Francis Bacon addressed to him, can be found: «[...] I willingly read your letters [...] and your works, by now so famous, they were written in subtle and diligent forms. You write about Physics, and I will think about it like you do» (Letters and life of Bacon, 1874; CoLOMBO, 1878). On his figure and on his courageous works of Copernican matrix cfr. Dizionario Biografico degli Italiani (DBI); De Leo and D. FilipPone, 1986; Colombo, 1878 cit.; Sortais, 1907.

$\left({ }^{8}\right)$ On his figure and activity: Boffito, 1993; Riboldi, 1875; MAGNi, 1933; LuCATELlo, 1949.

(9) Cfr. Dassano, 1998. Founded the Meteorological Observatory in the Barnabites' house at San Sebastian in Livorno, placed on the last floor, above the roof of the building, in two little rooms. At the start of the first daily registrations, Fr. Monte was soon contacted by the Imperial Observatory of Paris, founded in 1855 to gather meteorological information purely for military use. With these words he described, in April 24, 1870, his febrile activity, exercised with great passion, between one lesson and another, at Royal Lyceum of Livorno: «The assis- 
tance of an Observatory is so laborious; it takes my time for at least four hours a day and it requires a great sacrifice on my health and interest. Yet I continue till I can, if the Municipality believes, in its sensitivity, to give me whatever yearly cheque [...]. The observations be done at 6 a.m., at 9 a.m., 12 noon, 3 p.m., 6 p.m. and 9 p.m.; that is, every three hours and then the particular extraordinary observations. The observations are these: on the Barometer, Thermometer, Magnetometer, Pluviometer, Anemometer, Ozonometer [...]». He published many of his studies: Di alcuni perfezionamenti alla macchina di Atvood. Memoria [...] Parma, Tip. Reale, 1855; The Meteorological observations done in the Imperial and Royal Lyceum of Livorno by Professor Pietro Monte barnabite, 1858, Livorno 1859; Fallacità dei sistmometri isolati, Gazzetta livornese n. 1090, January 24, 1875 ; etc.

$\left({ }^{10}\right)$ Cfr. DBI, n. 9, 501-503.

$\left({ }^{11}\right)$ Cfr. DBI n. 38, 804-806.

$\left({ }^{12}\right)$ Matera, 1850. Some notes mss. for his biography can be found in the Historical Archives of the Barnabites in Rome (from that time on ASBR).

$\left({ }^{13}\right)$ Pellanda, 1906.

$\left({ }^{14}\right)$ GuANZATI, 1796. On his figure see DBI, n. 60, 245-246.

$\left({ }^{15}\right)$ Acts of Convention at Gravi (Alessandria) September 11-12, 1982; DBI n. 11, 167-170.

$\left({ }^{16}\right)$ Cfr. the Exterarum scholarum disciplina apud clericos regulares S. Pauli, Mediolani 1666 of Melchiorre Gorino (1605-1701).

$\left({ }^{17}\right)$ Look for example RicCAdONNA et. al., 2002; Boffito, 1982.

$\left({ }^{18}\right)$ Moreover, Fr. Mariano Alpruni (1733-1816) was an agronomist and appraised siviculturist. There were publications about some letters of Fr. Angelo M. Cortenovis in his work Elogio e lettere familiari del padre Angelo M. Cortenovis, Milan 1862, addressed to his brother Pier Maria and to the scholar Fr. Giovenale Sacchi, omitting unfortunately those purely scientific arguments «because alien from the aim of our Collections of lives, and because it would have been professions equipping them of the incision of monuments, ancient medals and coins de coded by the author» (Preface of the Editor, V).

$\left({ }^{19}\right)$ In 1992 there came the idea of a joint publication on Fr. Denza, and the proposal of a collaboration even inside our publications for the full valorization of the scientific contribution of our famous Fathers in the seismological field. But the time was not yet mature.

$\left({ }^{20}\right)$ Undoubtedly the preserved material in the reviewed letters has a notable importance, since dealing with immediate responses to queries coming from every side of the earth, even to the most curious, like the project concerning an «apparatus [which] after being improved will allow us ith profound studies, to travel by land and for the air spaces of the sky», sent to Fr. Bertelli: «New Gas for flying electric ball Animated spirit Gas. Flying man with a New Gas animated with Mechanical Electric Wings, above a Bicycle and blown up ball of Gas Spirit Essence with relative storage recipient of Spirit Gas. Very clear Mr. Professor Father Astronomer Bertelli. The Varnisher allows us to present this Project. To You excellent Father, if you believe, the constant study for resolving it. Thank you very much. His Servant [...]. This improved apparatus will allow with deep studies to travel by land and for the air spaces of the Sky. Extracted Gas Spirit from the purified trees from the watery more thast the forcepart. A Project of a Ball dirigible through a Bicycle with two Wings on the sides; of a Bicycle to be operated through pedals and Electricity, to be applied for the movements of the machine to open up the wings, and for closing it into form of a flying animal. The aerial globe of support made in a form of a Chifelle; containing only 10 cubic meters of Spirit Gas; with recipient annex to the machine with an essence of Living Spirit Gas; to increase its force, to increase or to decrease (the anonymous fake flying animal). And here is the secret of the New living spirit Gas; made of live wood, animated and spirituous, and gathered with cane of rubber and closed hermitically in an iron vase as Essence of spirit Gas, all the reunited force; both spirituous gas and gassy, it has to be gathered with many tubes of rubber and through the operator of rubber can be brought into the iron storage and has to be purified in the watery part and is called Spirit Gas which will be the $50 \%$ much more than the usual Gas which is made up of fossil carbon dead soul and no longer vegetarian and of a lightness of 50\% of the usual». $\left({ }^{21}\right)$ Some examples: «Monsieur Joseph Boffito, Collegio alla Querce, Florence. Monsieur, Nous avons bien reçu votre lettre du 12 courant et votre «Chronicon Meteorologicum». C'est un fort beau travail, malheureusement il est trop important pour les resources don't nous disposons actuellement. Peut-être dans quelques années, lorsque notre périodique aura pris un certain déeveloppement, pourrons nous disposer de sommes suffisantes pour envisager la publication de volumes pareils à celui dont vous nous proposez aimablement l'impression. Je me demande si l'Académie de Lincei, par l'intermédiaire de la Commision d'étude italianne, ne pourrait par envisager la publication de votre travail. Voulez-vous que jet ente une démarche auprès de cette Commission par l'intermédiaire de M. Ciraolo? Je la ferais très volontiers. En vous félicitant de votre beau travail et dans l'attente de vos instructions, je vous prie de croire, Monsieur, à l'assurance de mes sentiments les plus distingués. Raoul Montandon» (ASBR, Boffito Archive, Geneva May 24, 1927). Montandon was the Editor in chief of the scientific magazine Matériaux 
pour l'étude des calamites, publiés par le soins de la Société de Géographie de Genéve. Another example: «Very Illustrious Professor and dear Colleague. For many reasons (Excuse me for my bad Italian) I thank myself for having the occasion of writing to you. My readings of the «Universo» of Florence, this notable italian scientific publication, is much more than «the practical Meteorology» have tied me to You. - and I give to myself the freedom to translate them into French for our Ciel et Terre publication of Astronomy and Physics of the Globe etc. [...] about his studies on the [...] discovery in Pompei, and the Dioptra of Archimedes - the translation of the Dioptra of Hipparco will follow, if You allow me. All of these would mean that I and our «Ciel et Terre» would be honored for sending to us your writings which is interests us and the pure science and the history of this science of your country where I gained a lot of friends - like Fr. Alfani and Professor Abetti and Professor Ronchi etc. [...] (in Florence). With the hope for a good scientific collaboration, please receive my letter - from a great friend of Italy and a friend of Your science too. E. Lagrange» (ASBR, Boffito Archive, Bruxelles, November 29, 1927). Lagrange was the director of the magazine Ciel et Terre and Vice President of the Belgian Company of Astronomy.

$\left.{ }^{(22}\right)$ See nt. 2.

\section{REFERENCES}

Acts of Convention at Gravi (Alessandria) (1982): Giuseppe M. Boffito, Barnabita, un erudito del Novecento, September 11-12, (Leo Olschki Editore, Firenze, Italy), MCMLXXXIV.

BACON, F. (1874): The letters and the life of Francis Bacon, edited by SpEDding J., (Longman, London), VII, 374-377.

BARBARISI, G. (1987): Ideology and science in the opera of Paolo Frisi (1728-1784), (Franco Angeli, Milano, Italy).

BiAnchi, A. (2002), Barnabiti Studi, 19, 55-78.

Boffito, G. (1982): Gli strumenti della scienza e la scienza degli strumenti con l'illustrazione della tribuna di Galileo, (Multigrafica, Roma, Italy), (published for the first time in 1929).

Boffito, G. (1993): Barnabite Writers, I, (Olschki, Firenze, Italy), 443-453.

Colombo, G. (1878): Intorno alla vita e alle opera del Padre Redentor Baranzano (About the life and works of Fr. Redento Baranzano), (V. Bona, Torino, Italy), 58-61.

Dassano, F. (1998): Pietro Monte. Scientist, teacher and founder of the Nursery school of Tonengo, (Bolognino Editore, Ivrea), 79, (review edited by F. Lovison, in Eco dei Barnabiti, 3, 2003, 53-54).

De Leo, A. and D. Filippone (1986): Encounter with Baranzano: a discovery, Barnabiti studi, 3, 151-159.

Dizionario Biografico degli Italiani (DBI), Treccani Editore, www.treccani.it.

ERBA, A. (1981): The schools and the pedagogical tradition of the Barnabites, Experiences of Christian Pedagogy, I Roma, 173

FERRARI, G. (Ed.) (1991): Seismographic tromometer alarms. Observations and theories from 1850 to 1880 , (Ed. SGA, Bologna).

FERRARI, G. (1997): Cultural and scientific value of Seismology's heritage in Europe: why and how to preserve, extracted from the Cahiers du Centre Europeen de Ge- odynamique et de Seismologie, vol. 13, Luxemburg.

FERRARI, G. and M. BIANCHI (1997): Census, cataloguing and elaboration of scientific letters in Seismology, extracted from the Cahiers du Centre Europeen de Geodynamique et de Seismologie, vol. 13, Luxemburg.

Historical Barnabites Archives (ASBR), Roma, Italy.

GUANZATI, L. (1796): Osservazioni ed esperienze intorno a un prodigioso animaluccio delle infusioni, in «Opuscoli scelti», Milano, XIX, 3-31.

GuANZATI, L. (1819): Corso di storia naturale (ms) and the Relazione dei perfezionamenti arrecati dal sig. Stroppa alla macchina inventata dal Christian con cui si preparano senza macerazione il lino e la canapa.

Lucatello, E. (1949): Scientist Priests, (Società Editrice Life and Thought, Milano, Italy), 139-140.

Magni, G. (1933): P. Giovanni Maria Cavalleri, Physician, 1807-1874 in The Barnabites at Monza in the fourth centenary of the approval of the Order 1533-1933, (Tipography of the Mission, Milano, Italy), 85-90.

MATERA, L. (1850): Elementi di Trigonometria Rettilinea, $e$ Sferica compilata per le scuole de' Barnabiti dal P.D. ... , Naples, from Reale Tipografia Militari.

MicheLINI, V. (1956): La «ratio studiorum» and the educative method of the Barnabites, Quaderni per la scuola cattolica, 2.

Pellanda, G. (1906): La flora estiva dei monti d'Oropa, (Tipografia di G. Testa, Biella, Italy).

RiBoldI, A. (1875): Biographical outlines of M.R.P.D. Giovanni M. Cavalleri Barnabite (extracted from «The Catholic school», exercises XXVI and XXVII), (Serafino Grezzi, Milano, Italy), 48.

Riccadonna, G., P. Tucci, M. Zaninelli and M. Zulian (2002): La scienza in Collegio. Strumenti scientifici del Collegio S. Francesco in Lodi, (TREG, Guardamiglio (Lodi), Italy), 162, s.i.p.

SORTAIs, G. (1907): The Process of Galileo: historical and doctrinal study, (Roma, Desclee e Comp. Editori). 